\section{Magdalena Płotka}

Cardinal Stefan Wyszyński University in Warsaw magdalenaplotka@gmail.com

ORCID: 0000-0002-6993-2178

DOI: http://dx.doi.org/10.12775/BPTh.2019.016

\section{Biblica}

et

Patristica

Thoruniensia

12 (2019) 3: 289-301

ISSN (print) 1689-5150

ISSN (online) 2450-7059

\title{
Utrum fruendum sit solo Deo: Thomas Aquinas on the Augustinian Concept of Secular Enjoyment
}

\author{
Utrum fruendum sit solo Deo: \\ Tomasz z Akwinu o Augustyńskiej koncepcji \\ doczesnej radości
}

\begin{abstract}
The paper presents the hypothesis that Thomas Aquinas's concept of 'secular enjoyment has been elaborated under the influence of both St. Augustine (De doctrina christiana) and Aristotle (NE Book II and Book IV). The paper aims at presenting their influences upon Aquinas's account of secular enjoyment. In addition, it intends to focus on Aquinas's metaphysical and psychological concept of secular pleasure and attempts to introduce his moral assessment of it. It should be also noted that only natural perspective of pleasure will be discussed in the text; the theological aspect is excluded from the consideration.
\end{abstract}

Streszczenie. W artykule zaprezentowano tezę, zgodnie z którą koncepcja doczesnej radości według św. Tomasza z Akwinu powstała pod wpływem zarówno koncepcji św. Augustyna (De doctrina christiana), jak i Arystotelesa (zwłaszcza księgi II i IV Etyki nikomachejskiej). Celem artykułu jest po pierwsze pokazanie wpływów obydwóch filozofów na kształtowanie się koncepcji doczesnej radości Tomasza oraz po drugie, przedstawienie metafizyczne i psychologiczne jej ujęcie. Ponadto, artykuł prezentuje moralną ocenę Akwinaty dotyczącą ziemskich przyjemności. Należałoby jednak stwierdzić, że przedmiotem artykułu jest jedynie naturalna (doczesna) perspektywa radości; artykuł nie uwzględnia teologicznego kontekstu problemu radości i przyjemności.

Keywords: enjoyment; pleasure; secular enjoyment; St. Thomas Aquinas; St. Augustine.

Słowa kluczowe: radość; przyjemność; doczesna przyjemność; św. Tomasz z Akwinu; św. Augustyn. 


\section{Introduction}

$\circlearrowleft$ trum fruendum sit solo Deo is the title of one of the articles of St. Thomas Aquinas's commentary on the Sentences. It concerns the problem whether God alone is to be enjoyed, i.e. whether God alone could be the object of enjoyment (beatitude). Although Thomas's affirmative answer to the question might seem obvious, ${ }^{1}$ the problem itself provokes a reflection on the causes of human happiness and it raises also the question whether anything besides God, such as any created good, can be the object of enjoyment as well.

In the present paper, I explore the problem by considering Thomas's view of 'secular enjoyment'. The concept of 'secular enjoyment' connotates the general notion of pleasure which accompanies the human actions intended to acquire a created good. ${ }^{2}$ It includes mainly sensual pleasure (delectatio), joy (gaudium), ludic laughter and fun (ludus), the affective positivity of all joy, gladness, wellbeing, and enjoyment - all man's feeling good or happy. In other words, it refers to all human earthly experiences of enjoyment and pleasure, which are parts of their common psychological life. In the paper, then, I intend to analyze Aquinas's metaphysical and psychological concepts of secular enjoyment and I attempt to introduce his moral assessment of it. It should be also noted, that only natural perspective of pleasure will be treated while the theological aspect will be excluded from this reflection.

The problem of 'pleasure' or 'secular enjoyment' has been widely discussed in Thomistic scholarship for many years. It has become the subject of researchers' interest in many aspects: metaphysical, theological and psychological one. For instance, James F. Kramer wrote a dissertation devoted to the problem of metaphysical and psychological principles of pleasure in Aquinas, ${ }^{3}$ whereas Severin V. Kitanov concentrated on the theological aspect of enjoyment. ${ }^{4}$ There are also some works which elaborate the detailed problems concerning Thomistic concept of pleasure: Piotr Roszak focused on the ludic pleasure

1 Super Sent., lib. 1, d. 1, q. 2, a. 1, s. c. 1: “Contra, ratio dilectionis est bonitas. Sed omnis bonitas refertur ad bonitatem Dei a qua fluit et cujus similitudinem gerit. Ergo nihil est diligendum nisi in ordine ad Deum. Ergo solo Deo fruendum est."

2 The secular and natural aspect of enjoyment should be carefully separated from a religious concept of enjoyment. See S.V. Kitanov, Beatific Enjoyment in Medieval Scholastic Debates. The Complex Legacy of Saint Augustine and Peter Lombard, p. xiii.

3 See J.F. Kramer, The Metaphysical and Psychological Principles of Pleasure According to St. Thomas Aquinas, pp. 16-88.

4 See S.V. Kitanov, Beatific Enjoyment in Medieval Scholastic Debates. The Complex Legacy of Saint Augustine and Peter Lombard, pp. 35-37. 
in Thomas's account, ${ }^{5}$ and John G. Millhaven dedicated his article to the problem of sexual pleasure. ${ }^{6}$ In addition, there are some papers concerning pleasure and enjoyment in the framework of Aquinas's theory of emotions which are worth mentioning: ${ }^{7}$ for example, Martin Pickavés chapter on pleasure in Aquinas shows uniqueness of Thomas's account in the context of general view of medieval theories of emotions. ${ }^{8}$ However, the present paper attempts to look at the problem of 'secular enjoyment' from ethical point of view. Taking into consideration the metaphysical structure of enjoyment as such and its role in human psychology, the paper deals with Aquinas's moral evaluation of it. Although pleasure and joy belong to Thomas's theory of emotions and their basic understanding would require their explanation in the context of emotions, this paper is mainly interested in the morality of secular enjoyment. Thus, it rather focuses on the question of how Aquinas does morally justify the experience of pleasure and enjoyment in the mundane world.

Before I turn to the main arguments of the paper, first I will define the terminology which is used by St. Thomas to refer to pleasure and enjoyment. There are at least five terms: delectatio, gaudium, exultatio, laetitia and iucunditas. Delectatio is the most generic term, it denotes pleasure as such, ${ }^{9}$ but is also frequently used for pleasures of the appetitive sense. Gaudium is the term used in speaking of pleasure of a rational appetite and is frequently translated as 'joy.' ${ }^{10}$ The last of the three terms - exultatio, laetitia and iucunditas are called effects of gaudium and take their names from the specific effects they produce. ${ }^{11}$ The Aristotelian philosophy and tradition of the Church Fathers

5 See P. Roszak, Anatomy of ludic pleasure in Thomas Aquinas, pp. 50-71.

6 See J.G. Milhaven, Thomas Aquinas on sexual desire, pp. 157-181.

7 See S. Knuutila, Emotions in Ancient and Medieval Philosophy, pp. 239-255.

8 See M. Pickavé, Pleasure in Later Medieval Latin Philosophy. The case of Thomas Aquinas, pp. 99-123.

9 Summa theologiae Ia-IIae, q. 31, a. 3 co.: "Respondeo dicendum quod gaudium, ut Avicenna dicit in libro suo de anima, est quaedam species delectationis." All English translations of the Summa theologiae come from Benziger Bros. edition (1947), translated by the Fathers of the English Dominican Province.

10 Summa theologiae Ia-IIae q. 31, a. 3 co.: "Delectamur enim et in his quae naturaliter concupiscimus, ea adipiscentes; et in his quae concupiscimus secundum rationem. Sed nomen gaudii non habet locum nisi in delectatione quae consequitur rationem, unde gaudium non attribuimus brutis animalibus, sed solum nomen delectationis."

11 Summa theologiae Ia-IIae q. 31, a. 3 ad 3: "Ad tertium dicendum quod alia nomina ad delectationem pertinentia, sunt imposita ab effectibus delectationis, nam laetitia imponitur a dilatatione cordis, ac si diceretur latitia; exultatio vero dicitur ab exterioribus signis delectationis interioris, quae apparent exterius, inquantum scilicet interius gaudium prosilit 
constitute two important historical sources for Thomas's concept of pleasure and enjoyment. Thomas makes use of both of them, however, one can see in his work certain tension between Aristotle's secular ethics directed at the perfection of natural human potencies and the patristic vision of happiness dependent on God and located in the supernatural life. ${ }^{12}$ This paper argues that although Aristotle's influence on Aquinas's concept of pleasure was immense, it is noticeable in metaphysical detailed considerations in particular; however, Thomas's moral evaluation of the proper man's attitude towards earthly pleasures is thoroughly Patristic, it is Augustinian specifically.

It seems that St. Augustine is one of the most influential thinkers for Aquinas. ${ }^{13}$ His interpretation of enjoyment in De doctrina christiana, according to which any created good as such cannot be simply the object of pleasure, ${ }^{14}$ sets the theoretical (theological) frame of the discourse of enjoyment for Thomas and many other medieval scholars. ${ }^{15}$

Let me begin with a brief presentation of Augustinian concept of secular enjoyment. It has been expressed by the metaphor of life as a wandering. A man in his mortal life is like a wanderer, he seeks his happiness, as cannot live happily away from his fatherland. In order to get to the fatherland, a man has to make use of the world. Moreover, as Augustine writes: "the beauty of the country through which we pass and the very pleasure of the motion, charm our hearts, and turning these things which we ought to use into objects of enjoyment, we become unwilling to hasten the end of our journey; and becoming engrossed in a factitious delight, our thoughts are diverted from that home whose delights

ad exteriora; iucunditas vero dicitur a quibusdam specialibus laetitiae signis vel effectibus. Et tamen omnia ista nomina videntur pertinere ad gaudium, non enim utimur eis nisi in naturis rationalibus." See J.F. Kramer, The Metaphysical and Psychological Principles of Pleasure According to St. Thomas Aquinas, p. 16.

12 As Jessica Rosenfeld's investigation has shown, tension between Aristotelian and Augustinian concept of happiness was one of the main characteristics of 13th century ethics (since 1240), because reception of Aristotelian works helped to draw the attention of medieval scholars to the importance of earthly joy. See J. Rosenfeld, Ethics and Enjoyment in Late Medieval Poetry: Love after Aristotle, p. 4.

13 They raised both philosophical and theological issues on that matter; beyond the issue of moral evaluation of secular enjoyment, they focused on the problem of psychological and spiritual effects of pleasure and enjoyment, the relation between natural and supernatural enjoyment, etc. St. Ambrose, Tertullian and John Chrysostom - they all are mentioned in St. Thomas's doctrine on earthly enjoyment.

14 "Si vero inhaeseris atque permanseris, finem in ea ponens laetitia tuae, tunc vere et proprie frui dicendus es; quod non faciendum est nisi in illa Trinitate, is est summo et incommutabili bono." Augustine, De doctrina christiana I, XXXIII, 37; PL 34, col. 0033.

15 S.V. Kitanov, Beatific Enjoyment in Medieval Scholastic Debates, pp. 1-27. 
would make us truly happy." 16 Augustine makes two important distinctions here: the first distinction is between this world and "future fatherland" and the second one separates utitio and fruition - use and enjoyment. And next, he attributes enjoyment only to the latter. He makes it clear that "this world must be used, not enjoyed." ${ }^{17}$

The passage of De doctrina christiana turned out to be the crucial point for medieval debates, because the possibility of acquiring full enjoyment in the temporal world was questioned. Furthermore, enjoying the created world is morally ambiguous for Augustine, as he argues that all human desires are to be satisfied only by God. Thus, "Augustinian concept of secular enjoyment" is understood here as questioning the autonomous value of earthly joy and pleasure. And the question is, what use does Thomas make of this concept? Precisely, how does he justify man's ordinary everyday pleasures and joys?

\section{Thomas Aquinas vs. Augustine on the approval of worldly pleasures}

Thomas analyzes some cases of joy or pleasure in everyday human life. These examples come from various places of his works and generally occur in the context of a question of their proper moral character. The examples allow us to see Thomas's attitude towards everyday pleasures and they help us to specify his position about seeking trivial though enjoyable matters.

For instance, in the Secunda Secundae he asks a question whether eating for pleasure is a sin. He explains that it is indeed a sin if a man becomes attached to the pleasure of eating so much that pleasure itself becomes the purpose for which he neglects God. Such neglect would, in turn, involve performing an ac-

16 "Quomodo ergo, si essemus peregrini, qui beate vivere nisi in patria non possemus, eaque peregrinatione utique miseri et miseriam finire cupientes, in patriam redire vellemus, opus esset vel terrestribus vel marinis vehiculis quibus utendum esset ut ad patriam, qua fruendum erat, pervenire valeremus; quod si amoenitates itineris et ipsa gestatio vehiculorum nos delectaret, conversi ad fruendum his quibus uti debuimus, nollemus cito viam finire et perversa suavitate implicati alienaremur a patria, cuius suavitas faceret beatos: sic in huius mortalitatis vita peregrinantes a Domino, si redire in patriam volumus, ubi beati esse possimus, , ut invisibilia Dei, per ea quae facta sunt, intellecta conspiciantur, hoc est, ut de corporalibus temporalibusque rebus aeterna et spiritalia capiamus." Ibidem, col. 020-021

17 "Utendum est hoc mundo, non fruendum." Ibidem, col. 020-021 
tion which brings pleasure and, at the same time, it would be contrary to the commandments of God. ${ }^{18}$

Let us compare Aquinas's and Augustine's evaluation of enjoying the meal: in Confessiones Augustine claims that eating is sinful always when it accompanies a purpose other than satisfying hunger and biological survival of the body. ${ }^{19}$ Neither Thomas, nor Augustine judges negatively the pleasure itself as it accompanies eating. There is nothing sinful when while eating a meal man will appreciate the delicious taste of food and the accompanying pleasure. However, inasmuch as Thomas does not judge pleasure negatively even if it becomes a purpose in itself (e.g., if someone enjoys nutritionally unprofitable but very tasty meal), Augustine argues that choosing pleasure as a purpose in itself (e.g., if someone reaches for a chocolate for pure pleasure) covers the correct (final) purpose. This is why it is so sinful. Thomas, by contrast, recognizes sinful pleasure only in the case if a man selects pleasure while choosing between pleasure and fulfilling commandments of God.

Analogically, Thomas speaks about drinking wine in a positive way: "Wine drunken with moderation is the joy of the soul and the heart," ${ }^{20}$ he observes in the Summa theologiae. He also considers neglect of certain worldly matters for instance, an outfit - as inappropriate and flawed. In the question dedicated to the issue of "modesty as consisting in the outward movements of the body" (de modestia secundum quod consistit in exterioribus motibus corporis, II ${ }^{\text {a-IIae, }}$ q. 168) Aquinas analyzes such virtues like "taste" (ornatus) and "methodicalness" (bonam ordinationem) ${ }^{21}$ He claims that both virtues rely on capability to behave, a certain sense of what is convenient and what is not. One of the tests of whether someone is equipped with the virtues of methodicalness and taste is his ability to choose the right outfit, as well as the right position of the body. Thomas concludes that "outward movements are signs of the inward disposi-

18 Summa theologiae IIa-IIae, q. 148, a. 2 co.: "Quod quidem contingit quando delectationi gulae inhaeret homo tanquam fini propter quem Deum contemnit, paratus scilicet contra praecepta Dei agere ut delectationes huiusmodi assequatur."

19 Augustine, Confessionum Libri Tredecim, PL 32, col. 0787; col. 0799-0800; col. 0657-0868.

20 Summa theologiae II ${ }^{\text {a }}$-IIae, q. 149 a. 3 s. c.: "Et Eccli. XXXI dicitur, exultatio animae et cordis vinum moderate potatum."

21 Summa theologiae II"-IIae, q. 168 a. 1 co.: "Et ideo circa huiusmodi exteriores motus ponit Andronicus duo. Scilicet ornatum, qui respicit convenientiam personae, unde dicit quod est scientia circa decens in motu et habitudine. Et bonam ordinationem, quae respicit convenientiam ad diversa negotia et ea quae circumstant, unde dicit quod est experientia separationis, idest distinctionis, actionum." 
tion, according to Ecclus. 19:27, «the attire of the body, and the laughter of the teeth, and the gait of the man, show what he is»".22

Therefore, according to Aquinas, one should take care of the appropriate outfit, not to avoid wine and, consequently, to appreciate the pleasure of eating tasty meals. Thomas positively evaluates the pleasures accompanying natural activities. ${ }^{23}$ As I will argue, his positive attitude to pleasure is the result of the influences of Aristotle's ethical theory.

It should be noted that Augustinian and Aristotelian traditions do not resonate with each other and are in tension in regard to the evaluation of worldly pleasures. Following Aristotle (and against Augustine) Thomas claims that avoiding pleasure deliberately can be a vice. He formulates two arguments for this thesis: metaphysical and moral. The former concerns the connection between pleasure and the order of nature. Aquinas explains that temperance requires usage of pleasures, which are necessary for health and well-being.

Whatever is contrary to the natural order is vicious. Now nature has introduced pleasure into the operations that are necessary for man's life. Wherefore the natural order requires that man should make use of these pleasures, in so far as they are necessary for man's well-being, as regards the preservation either of the individual or of the species. Accordingly, if anyone were to reject pleasure to the extent of omitting things that are necessary for nature's preservation, he would sin, as acting counter to the order of nature. And this pertains to the vice of insensibility. ${ }^{24}$

The argument attempts to explain the vice of insensibility. It presents the following reasoning: (1) since all activities necessary for the survival of man (as an individual and as a species) are accompanied by pleasure (eating, drinking, reproduction, social life, etc.), and (2) human survival is determined by the order of nature which means that nature dictates the principles on which survival depends, and (3) the order of nature comes from God and as such

22 Summa theologiae IIa-IIae, q. 169, a. 1, ad. 1: "Ad primum ergo dicendum quod motus exteriores sunt quaedam signa interioris dispositionis, secundum illud Eccli. XIX, amictus corporis, et risus dentium, et ingressus hominis, enuntiant de illo."

23 See P. Roszak, Anatomy of ludic pleasure in Thomas Aquinas, pp. 50-71.

24 Summa theologiae II ${ }^{\mathrm{a}}$-IIae, q. 142, a. 1 co.: "Respondeo dicendum quod omne illud quod contrariatur ordini naturali, est vitiosum. Natura autem delectationem apposuit operationibus necessariis ad vitam hominis. Et ideo naturalis ordo requirit ut homo intantum huiusmodi delectationibus utatur, quantum necessarium est saluti humanae, vel quantum ad conservationem individui vel quantum ad conservationem speciei. Si quis ergo intantum delectationem refugeret quod praetermitteret ea quae sunt necessaria ad conservationem naturae peccaret, quasi ordini naturali repugnans. Et hoc pertinet ad vitium insensibilitatis." 
is good, therefore (4) the pleasure resulting from activities compatible with nature is a part of this nature ${ }^{25}$ and is good as such. In consequence, Aquinas claims that a deliberate avoidance of pleasure is flawed because it goes beyond the order of nature. Thomas applies this reasoning while considering a fast. He explains that it is morally correct when someone renounces the pleasure accompanying, for example, eating (e.g., if one decides to eat small and tasteless portions of food) as a part of fasting. However, if someone gives up eating as a part of fasting only because he or she wants to avoid any pleasure which comes from it, this activity is considered by Aquinas as a contrary to reason.

The second argument for the defectiveness of avoiding worldly pleasures is inspired by the II and IV books of the Nicomachean Ethics. It concerns insensibility (a tendency of avoiding pleasure) as a vice of character. "The Philosopher reckons the lack of mirth to be a vice," ${ }^{26}$ Thomas repeats after Aristotle while he considers the case of people deprived of sense of humor:

Now a man who is without mirth, not only is lacking in playful speech, but is also burdensome to others, since he is deaf to the moderate mirth of others. Consequently they are vicious, and are said to be boorish or rude, as the Philosopher states. ${ }^{27}$

Thus, lack of sense of humor is a social disadvantage (such people are unbearable for the others). Lack of mirth and humor justify also mental dullness and insensibility.

Thomas, therefore, sees pleasure and enjoyment as a natural part of human experience, i.e. the experience that both flows from natural life activities of man and supports and complements his nature - sunt autem bona sensibilia connaturalia homini. ${ }^{28} \mathrm{He}$ appreciates earthly pleasures much more than Augustine.

Yet, for the complete recognition of Aquinas's concept of secular enjoyment one should answer the question about the position of 'secular enjoyment' in the order of human desires and their ends, in other words, whether worldly pleasure is autonomous and can be itself the purpose of human action.

25 In IV Sent., d. 49, q. 4, ad. 4.

26 Summa theologiae II'-IIae, q. 168, a. 4 s. c.: "Sed contra est quod philosophus, in II et IV Ethic., ponit defectum in ludo esse vitiosum."

27 Summa theologiae IIa-IIae, q. 168, a. 4 co.: "Illi autem qui in ludo deficiunt, neque ipsi dicunt aliquod ridiculum; et dicentibus molesti sunt, quia scilicet moderatos aliorum ludos non recipiunt. Et ideo tales vitiosi sunt, et dicuntur duri et agrestes, ut philosophus dicit, in IV Ethic."

28 Summa theologiae II ${ }^{\mathrm{a}}-\mathrm{IIae}, \mathrm{q} .168$, a. 2 co. 


\section{Is secular enjoyment autotelic? Aquinas's response}

In the Summa theologiae, Thomas attempts to solve this problem by distinguishing between external and internal ends. He claims that enjoyment does not have any external end as it is directed only at the well-being of the person having fun. However, it does have its internal purpose:

Playful actions themselves considered in their species are not directed to an end: but the pleasure derived from such actions is directed to the recreation and rest of the soul, and accordingly if this be done with moderation, it is lawful to make use of fun. Hence Tully says (De Offic. i, 29): "It is indeed lawful to make use of play and fun, but in the same way as we have recourse to sleep and other kinds of rest, then only when we have done our duty by grave and serious matters". 29

Thus, enjoyment has only a regenerative function. It is not an end in itself, its function relies rather on recreatio animae. Enjoyment helps to restore the physical and intellectual strength. An intense intellectual life would lose its effectiveness, if it is not interrupted by fun, Thomas argues. As Thomas observes in Contra Gentiles, enjoyment is just a mean, it provides the mind with rest:

Nor do we find any action in human affairs, except speculative thought, that is not directed to some other end. Even sports activities, which appear to be carried on without any purpose, have a proper end, namely, so that after our minds have been somewhat relaxed through them we may be then better able to do serious jobs. ${ }^{30}$

Consequently, secular enjoyment has no autotelic status, it has rather functional value - Aquinas claims - because it serves other purposes; precisely, it serves to realize the natural needs and desires of man, especially those related to the reasonable nature of man. Moreover, Thomas treats temporal pleasures as purposeful acts to such a degree that the experience of "joy without purpose",

29 Summa theologiae II-IIae, q. 168, a. 2 ad 3: "Ad tertium dicendum quod ipsae operationes ludi, secundum suam speciem, non ordinantur ad aliquem finem. Sed delectatio quae in talibus actibus habetur, ordinatur ad quandam animae recreationem et quietem. Et secundum hoc, si moderate fiat, licet uti ludo. Unde Tullius dicit, in I de Offic., ludo et ioco uti quidem licet, sed, sicut somno et quietibus ceteris, tunc cum gravibus seriisque rebus satisfecerimus."

30 Contra Gentiles, lib. 3, cap. 25, n. 9: "Nec invenitur aliqua actio in rebus humanis quae non ordinetur ad alium finem, nisi consideratio speculativa. Nam etiam ipsae actiones ludicrae, quae videntur absque fine fieri, habent aliquem finem debitum, scilicet ut per eas quodammodo mente relevati, magis simus postmodum potentes ad studiosas operationes." 
i.e. a joy in which neither its subject nor its object relate to any purpose, assigns only to animals. ${ }^{31}$

\section{Aquinas on enjoying a created good}

The view that enjoyment does not have an autotelic status and is only a mean to an end is shared by both Thomas and Augustine. Both thinkers describe enjoyment in teleological schema, however, the schemas are not identical. Inasmuch as Augustine treats enjoying a created good as a simple mean to an end which is fruition, Aquinas does not see relation between secular enjoyment and fruition as direct. He introduces the category of 'nature' and argues that action resulting in enjoyment completes and supports nature and for this reason one should rather appreciate pleasurable and enjoyable actions, than to avoid them. It seems important to notice a close connection between enjoyment and nature in Aquinas's approach. All of his arguments in favor of pleasure are based on the assumption that everything that perfects nature, including enjoyment, is worthy. Therefore, the relation between enjoyment and fruition is mediated by nature in such a way that enjoyment supports and perfects nature, and perfection of nature is the implementation of the ultimate end.

It can be thus assumed that introducing the category of 'nature' into the consideration on pleasure was done under the influence of Aristotle. Nonetheless, as a Christian theologian, Aquinas understands 'nature' differently than it is recognizable in Aristotelian philosophy. He incorporates the three Aristotelian aspects of human nature: vegetative, sensual and intellectual, but he also emphasizes the supernatural aspect of a human being. By doing so, Aquinas is able to combine Augustinian (theological) and Aristotelian (philosophical) approaches.

In the Prima Secundae he raises the problem of whether a created good can be the object of true happiness (beatitude). Obviously, his answer is negative, but his argument evokes two important issues: firstly, human nature goes beyond the created world and secondly, this makes enjoying created natural good non-autotelic. Aquinas cannot accept the belief, that human nature is limited to creation only, and such nature is able to perfect itself only in the scope of creation. As a result, he rejects the claim that human pursuit of happiness is limited

31 Sent., lib. 1 d. 1, q. 4, a. 1, arg. 2: "Praeterea, fruitio est ejus quod per se quaeritur, non relatum ad alterum. Sed bruta quaerunt aliqua in quibus delectantur et non referunt ad aliud, quia carent ratione ordinante. Ergo brutorum est fruitio." 
to created goods. ${ }^{32}$ The reason of Thomas's denial is twofold: first, there is his clear attachment to Augustinian theology (whom he cites expressis verbis) according to which only God is the cause of human happiness; ${ }^{33}$ and second, he denies a restriction of human desires to the created world. Rather, he prefers to admit that human desires reach out to an uncreated good. ${ }^{34}$

I answer that, it is impossible for any created good to constitute man's happiness. For happiness is the perfect good, which lulls the appetite altogether; else it would not be the last end, if something yet remained to be desired. Now the object of the will, i.e. of man's appetite, is the universal good; just as the object of the intellect is the universal true. Hence it is evident that naught can lull man's will, save the universal good. This is to be found, not in any creature, but in God alone; because every creature has goodness by participation. Wherefore God alone can satisfy the will of man, according to the words of Ps. 102:5: "Who satisfieth thy desire with good things". Therefore God alone constitutes man's happiness. ${ }^{35}$

By extending the Aristotelian concept of nature to a spiritual aspect, Thomas can maintain the Augustinian thesis of the non-autonomous character of 'secular enjoyment' (he subordinates it to the ultimate end) and at the same time he can accept the significance of earthly pleasures.

32 Summa theologiae Ia-Iiae, q. 2, a. 8, arg. 3: "Praeterea, per hoc homo efficitur beatus, quod eius naturale desiderium quietat. Sed naturale desiderium hominis non extenditur ad maius bonum quam quod ipse capere potest. Cum ergo homo non sit capax boni quod excedit limites totius creaturae, videtur quod per aliquod bonum creatum homo beatus fieri possit".

33 Summa theologiae I-Iiae, q. 2, a. 8 sc.: "Sed contra est quod Augustinus dicit, XIX de Civ. Dei, ut vita carnis anima est, ita beata vita hominis Deus est; de quo dicitur, beatus populus cuius dominus Deus eius."

34 Summa theologiae Ia-Iiae, q. 2, a. 8 ad 3: "Ad tertium dicendum quod bonum creatum non est minus quam bonum cuius homo est capax ut rei intrinsecae et inhaerentis, est tamen minus quam bonum cuius est capax ut obiecti, quod est infinitum. Bonum autem quod participatur ab Angelo, et a toto universo, est bonum finitum et contractum".

35 Summa theologiae Ia-IIae, q. 2, a. 8 co.: "Respondeo dicendum quod impossibile est beatitudinem hominis esse in aliquo bono creato. Beatitudo enim est bonum perfectum, quod totaliter quietat appetitum, alioquin non esset ultimus finis, si adhuc restaret aliquid appetendum. Obiectum autem voluntatis, quae est appetitus humanus, est universale bonum; sicut obiectum intellectus est universale verum. Ex quo patet quod nihil potest quietare voluntatem hominis, nisi bonum universale. Quod non invenitur in aliquo creato, sed solum in Deo, quia omnis creatura habet bonitatem participatam.” 


\section{Conclusion}

To sum up, in order to answer the question posed in the title whether any created good can be enjoyed, two distinctions seem to be helpful. First of all, Aquinas discerns between fruitio (beatitude, happiness) and enjoyment. The latter concerns all kinds of pleasures, fun and well-being, whereas the former refers to the divine fulfillment of all human desires. A created good can be enjoyed only in the second sense. Secondly, although there is a strict structural difference between delectatio (pleasure of the sensual appetite) and gaudium (act of a rational will), in the context of enjoying a created good, it does not hold since instead of the Aristotelian opposition between sensual and intellectual, Thomas adopts the Augustinian antagonism between the uncreated (God) and the created (the world).

In regard to moral justification of enjoying created good, Thomas remains in the Patristic-Augustinian tradition and theoretical framework. He ascribes merely functional role to secular enjoyment, assigns it to the final end, and sees neither in his philosophical nor theological reflection the ratio for autotelic status of pleasure. However, unlike Augustine, Thomas appreciates and approves earthly pleasure. As we have seen above, he argues, that there is nothing sinful in enjoying a created good (contrasted with enjoying God). On the contrary, it is recommended and should not be avoided, since earthly pleasure and enjoyment play the important role in flowering and perfecting human nature (as far as they prepare soul and body for performing their natural activities).

\section{Bibliography}

[Augustine] S. Aurelii Augustini, Confessionum Libri Tredecim, Patrologia Latina, vol. 32, Parisi 1844-1855, col. 0657-0868.

[Augustine] S. Aurelii Augustini, De Doctrina Christiana Libri Quatuor, Patrologia Latina, vol. 34, Parisi 1844-1855, col. 0015-00122.

De Haan D., "Delectatio, gaudium, fruitio. Three Kinds of Pleasure for Three Kinds of Knowledge in Thomas Aquinas," Quaestio, 15, 2015, pp. 543-552.

Kitanov S.V., Beatific Enjoyment in Medieval Scholastic Debates. The Complex Legacy of Saint Augustine and Peter Lombard, New York 2018.

Knuutila S., Emotions in Ancient and Medieval Philosophy, Oxford 2004.

Kramer J.F., The Metaphysical and Psychological Principles of Pleasure According to St. Thomas Aquinas, Chicago 1958.

Milhaven J.G., "Thomas Aquinas on sexual desire," Journal of Religious Ethics, vol. 5, (no. 2), 1977, pp. 157-181. 
Pickavé M., "Pleasure in Later Medieval Latin Philosophy. The case of Thomas Aquinas," in Pleasure. A History, L. Shapiro (ed.), Oxford 2018, pp. 99-123.

Rosenfeld J., Ethics and Enjoyment in Late Medieval Poetry: Love after Aristotle, Cambridge 2011.

Roszak P., "Anatomy of Ludic Pleasure in Thomas Aquinas," Pensamiento y Cultura, vol. 16/2, 2013, pp. 50-71. 